\title{
TWO NEW SPECIES OF NEPENTHES (NEPENTHACEAE) FROM NORTH SUMATRA
}

\author{
CH'IEN C. LEE ${ }^{1}$, HERNAWATI $^{2} \&$ PITRA AKHRIADI ${ }^{2}$
}

\begin{abstract}
SUMMARY
Two new species of Nepenthes (Nepenthaceae) from North Sumatra, Nepenthes jamban Chi.C. Lee, Hernawati \& P. Akhriadi and Nepenthes lingulata Chi.C. Lee, Hernawati \& P. Akhriadi, are described and illustrated.
\end{abstract}

Key words: Nepenthes jamban, $N$. lingulata, North Sumatra.

\section{INTRODUCTION}

Despite the fact that the genus Nepenthes of Sumatra has received recent thorough treatment (Jebb \& Cheek, 2001; Clarke, 2001), several new species have recently been described including N. izumiae (Clarke et al., 2003) and N. rigidifolia (Akhriadi et al., 2004) making it clear that our present knowledge of the species diversity on this island is incomplete.

During a series of field trips to the island in 2004 and 2005, two taxa of Nepenthes were observed and collected from a single mountain in North Sumatra. Both of these taxa possessed a unique combination of features which served to easily distinguish them from all other known Nepenthes, and the lack of possible putative parents at the locality excluded their possibility of being natural hybrids. Further comparisons of these with specimens of related species confirmed that they represent new and undescribed taxa.

Nepenthes jamban and $N$. lingulata represent taxa which are closely related to other Sumatran species, namely N. jacquelineae C. Clarke, Troy Davis \& Tamin and N. izumiae Troy Davis, C. Clarke \& Tamin. These species conform to a common trend among highland Sumatran Nepenthes in which vicariance appears to have resulted in many similar but distinct taxa being isolated on one or a few mountain tops.

As discussed by Clarke (2001) the centre of diversity of Nepenthes in Sumatra appears to be the Barisan mountain range. This mountain chain which runs roughly north-south on the western edge of Sumatra, contains peaks of both igneous and sedimentary formations. Clarke considered the majority of highland Sumatran Nepenthes to be generally divided into two regions in the Barisan range, those of Aceh and the Danau Toba area, and those of the highlands from Padang to Jambi. However, more explorations in the

1) Forest Research Center, Sarawak Forestry, Km 10, Jalan Stephen Kalong Ningkan, 93250 Kuching, Sarawak, Malaysia; e-mail: cclborneo@ myjaring.net

2) Herbarium Universitas Andalas (ANDA), Kamus Unand, Limau Manih, Padang, Sumatera Barat, Indonesia; e-mail: sumatrannepenthes@yahoo.com 
area between these regions may reveal a less distinct division (Clarke, pers. comm.). Despite having an origin somewhat north of the Padang highlands, $N$. jamban and $N$. lingulata clearly fall within the latter group due to their close affinity with the species from that region.

With the addition of these species including $N$. jacquelineae and $N$. izumiae, and with the recognition of $N$. tenuis Nerz \& Wistuba, the key to Sumatran and Javan species of Nepenthes in Cheek \& Jebb (2001: 22-23) should be modified as follows:

6a. Peristome lacking on upper pitchers $\ldots \ldots \ldots \ldots \ldots \ldots \ldots \ldots$. inermis

6b. Peristome present on upper pitchers . . . . . . . . . . . . . 7

(7a.) Lid bearing several very large nectar glands ( $\leq 0.5 \mathrm{~mm}$ diam.) on the lower

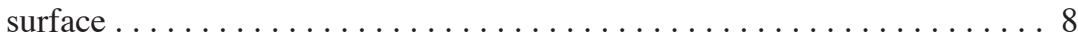

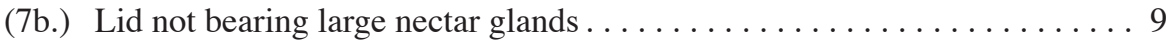

(8a.) Peristome of the upper pitchers expanded and extremely broad $(\geq 3.5 \mathrm{~cm}$

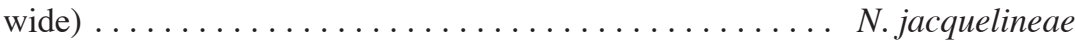

(8b.) Peristome of the upper pitchers not expanded ( $\leq 0.6 \mathrm{~cm}$ wide $) \ldots$ N. jamban

(9a.) Lid of upper pitchers reflexed beyond $180^{\circ}$ away from mouth . . . N. dubia

(9b.) Lid of upper pitchers never reflexed beyond $90^{\circ}$ away from mouth. N. tenuis

30a. Upper pitchers distinctly ventricose below, tubular above . . . . . . . 31

30b. Upper pitchers infundibuliform or ellipsoid throughout. . . . . . . . 34

(31a.) Glandular appendage present on underside of lid ............. 32

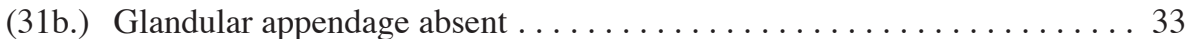

(32a.) Lid sub-orbicular, appendage broad, $\leq 1.5 \mathrm{~cm}$ long $\ldots \ldots \ldots \ldots$. izumiae

(32b.) Lid broadly triangular, appendage filiform, $\geq 2.2 \mathrm{~cm}$ long . . . . N. lingulata

(33a.) Peristome and pitchers rigid, somewhat woody $\ldots \ldots \ldots \ldots \ldots$ diatas

(33b.) Peristome and pitchers papery in texture . . . . . . . . . . singalana

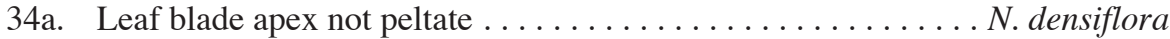

34b. Leaf blade apex peltate $\ldots \ldots \ldots \ldots \ldots \ldots \ldots \ldots \ldots \ldots \ldots \ldots$. bongso

Nepenthes jamban Chi.C. Lee, Hernawati \& P. Akhriadi, spec. nov. - Fig. 1

$N$. jacquelineae simile sed peristomii operculo valde porcato neque lato expanso, ascidii super valde abrupte infundibuliformibun et pedicellis in toto uniflorius differt. - Typus: Lee, Hernawati, Akhriadi NP 433 (ANDA), Indonesia, Sumatera Utara, Bukit Barisan, south of Padang Sidempuan, 22 April 2005.

Terrestrial climber to c. $4 \mathrm{~m}$ tall. Stems of rosettes and short shoots cylindrical-angular, c. $3 \mathrm{~mm}$ diam., internodes $1-1.3 \mathrm{~cm}$ long. Climbing stems to $0.5 \mathrm{~cm}$ diam., internodes $1.8-5 \mathrm{~cm}$ long. Leaves of rosettes coriaceous, sessile, narrowly obovate to elliptic or slightly spathulate, apex acute, $9-10.3$ by $2.2-3 \mathrm{~cm}$, clasping stem for $3 / 4$ circumference; longitudinal veins 1 or 2 on each side of the midrib, located in the outer $1 / 4$ of the lamina, pinnate veins arising obliquely from the midrib; tendrils straight, to $13 \mathrm{~cm}$ long. Leaves of climbing stems as those of rosettes, but lamina ovate to elliptic to slightly spathulate, usually contracted into a parallel-sided basal section, $7-11$ by $2.6-3.3 \mathrm{~cm}$, base clasping the stem for $1 / 2-2 / 3$ of its circumference and not decurrent; tendrils with a curl in the middle, $15-24 \mathrm{~cm}$ long. Lower pitchers originating laterally from the tendril, $3.5-5.8$ by $3.2-4.4 \mathrm{~cm}$, cylindrical to narrowly infundibular in the lower 
third, rapidly becoming widely infundibular above, somewhat compressed laterally, not hipped, mouth almost horizontal; inner surface glandular throughout; wings usually present on the front of the pitcher, to 10 by $2 \mathrm{~mm}$ wide with fringe elements c. $3 \mathrm{~mm}$ long; peristome flattened, to $0.8 \mathrm{~cm}$ wide, joined to the pitcher in the outer third, the inner side slightly incurved; ribs c. $0.7 \mathrm{~mm}$ apart at front, closer and less pronounced towards lid; inner margin ending in teeth c. $0.5 \mathrm{~mm}$ long; spur usually simple, sometimes forked, inserted at base of lid, c. $4 \mathrm{~mm}$ long; lid narrowly obovate, $3.5-3.8$ by $0.9-1.3 \mathrm{~cm}$, held horizontally over the mouth, with sides folded upwards at c. $120^{\circ}$, undersurface with scattered small red glands concentrated around the midrib and a few (c. 20-30) very large crater-like glands, c. $0.5 \mathrm{~mm}$ diam., present in the apical 1/4, which are visible on the upper surface of the lid as distinct swellings. Upper pitchers originating from the tendril at the rear of the pitcher, $7.5(-12)$ by $5.2 \mathrm{~cm}$, expanding very gradually in the lower half and abruptly becoming widely infundibular in the upper half, circular in cross section, not hipped, mouth horizontal and orbicular; inner surface glandular throughout; wings absent but present in lower half of pitcher as reduced ribs; peristome flattened, to $0.6 \mathrm{~cm}$ wide, joined to the pitcher in the outer third, ribs c. $1 \mathrm{~mm}$ apart and $0.5 \mathrm{~mm}$ tall; inner margin ending in teeth c. $1 \mathrm{~mm}$ long; spur usually simple, inserted at base of lid, to $3.5 \mathrm{~mm}$ long; lid as in lower pitchers but longer, to 4.8 by 0.9 $\mathrm{cm}$, held over the mouth at an angle of c. $45^{\circ}$. Male inflorescence a raceme, 18 by 2 $\mathrm{cm}$; peduncle to $4.2-6.5 \mathrm{~cm}$ long, rachis $8.2-11.5 \mathrm{~cm}$, pedicels $0.5-1.4 \mathrm{~cm}$ long, each bearing a single flower, with a filiform bract $2-9 \mathrm{~mm}$ long inserted c. $1 \mathrm{~mm}$ from the base of the pedicel; sepals elliptical, c. $3.5 \mathrm{~mm}$ long; staminal column $1.5-3 \mathrm{~mm}$ long. Female inflorescence unknown. Ripe infructescence a raceme, peduncle $5 \mathrm{~cm}$ long, rachis $3 \mathrm{~cm}$ long, pedicels to $1.4 \mathrm{~cm}$ long, each bearing a single fruit, with a filiform bract c. $4 \mathrm{~mm}$ long inserted c. $2 \mathrm{~mm}$ from the base of the pedicel; fruit to 3 by $0.6 \mathrm{~cm}$; seeds filiform, c. $2 \mathrm{~cm}$ long. Indumentum: all parts of the plant glabrous except for developing pitchers, tendrils, and inflorescence which are densely covered with short brownish grey hairs. Colour of living specimens: leaves light green above, pale green below, stems purplish red, inflorescence light green, lower pitchers yellowish orange to bright red with red peristome, upper pitchers bright yellow occasionally with red spots on inner surface and with yellow to orange peristome.

Distribution - Sumatra (Sumatera Utara, Bukit Barisan).

Habitat - Upper montane mossy forest and summit scrub vegetation, growing terrestrially.

Etymology - The specific name refers to the word 'jamban' in Indonesian, due to the resemblance of the pitcher shape to a toilet receptacle.

Notes - This species represents another taxon in the primarily West Sumatran group which includes $N$. dubia, N. inermis, $N$. jacquelineae, and $N$. tenuis. With these species it shares common features including broadly infundibulate pitchers which are wholly glandular within, bracteate inflorescences, and sessile leaves. In addition, all these species have a highly viscous pitcher fluid, and it has been suggested that this may aid in the retention of insect prey, as mentioned by Clarke (2001).

The upper pitchers of $N$. jamban have been regularly observed to be filled with numerous large insect prey items including wasps and crickets and with very few small prey such as ants. Most upper pitchers also support large populations of living mosquito larvae. 


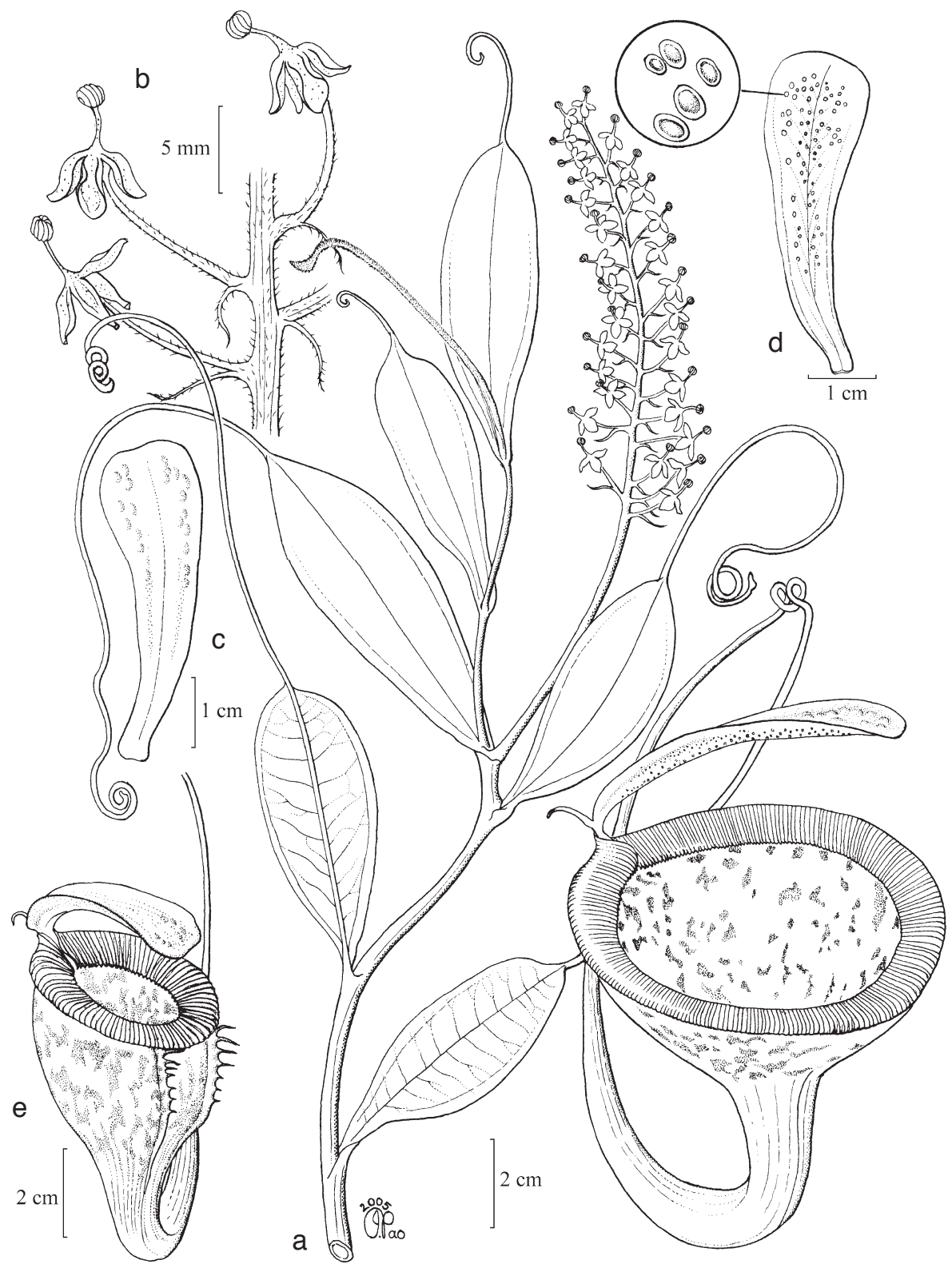

Fig. 1. Nepenthes jamban Chi.C. Lee, Hernawati \& P. Akhriadi. a. Climbing stem with upper pitcher and male inflorescence; b. detail of male inflorescence; c. upper surface of pitcher lid; d. lower surface of pitcher lid; e. lower pitcher (all from photographs). Drawing by Joseph Pao. 
Nepenthes jamban appears most closely related to $N$. jacquelineae with which it shares a similar growth habit and pitcher structure. Both of these species possess unusually large nectar glands on the undersurface of the pitcher lid which are so robust that they produce small bumps on the lid's upper surface. However, $N$. jacquelineae differs in having a more robust habit, a widely expanded smooth peristome, shorter and 2-flowered partial peduncles, and a wider pitcher lid.

At the type locality (currently the only known locality for this species), N. jamban is sympatric with $N$. bongso, $N$. dubia, $N$. gymnamphora, and $N$. lingulata, though no natural hybrids have been observed. The fact that the closely related $N$. dubia occurs in the same habitat with no apparent introgression is worthy of note as this is the first record of two sympatric taxa in this species group.

Photos displayed recently (2005-2006) on http://www.wistuba.com illustrate an undescribed Nepenthes species which resembles $N$. jamban but differs in having a broad ovate or oblong pitcher lid. No specimens of this taxon are available for further examination.

Other specimens examined:

Nepenthes jacquelineae - Clarke, Davis \& Tamin 1307 (holo ANDA), 1308 (iso ANDA), Nepenthes Team NP 384 (ANDA).

Nepenthes lingulata Chi.C. Lee, Hernawati \& P. Akhriadi, spec. nov. - Fig. 2

$N$. izumiae simile sed operculis ascidiorum base triangularibus-cordatibun, appendice ascidiorum curvata elongata, glandularum nectariarum apicis appendicis dispositis differt. - Typus: Lee, Hernawati, Akhriadi NP 432 (holo ANDA), Indonesia, Sumatera Utara, Bukit Barisan, south of Padang Sidempuan, 22 April 2005.

Terrestrial or epiphytic climber to c. $5 \mathrm{~m}$. Stems of rosettes and short shoots terete, to $0.4 \mathrm{~cm}$ diam., internodes $1 \mathrm{~cm}$ long. Climbing stems terete, to $4 \mathrm{~mm}$ diam., internodes $3.5-9 \mathrm{~cm}$ long. Leaves of rosettes coriaceous, sessile, lanceolate, apex acute, to 9.6 by $3 \mathrm{~cm}$, clasping stem for $3 / 4$ circumference, in live specimens the upper surface of lamina with a depressed longitudinal groove on either side of the midrib running the length of the leaf; longitudinal veins 2 on either side of the midrib; tendril straight, to $25 \mathrm{~cm}$ long. Leaves of climbing stems as those of rosettes but smaller, elliptical-ovate, $3.7-4.8$ by $1-2.1 \mathrm{~cm}$; tendril to $14 \mathrm{~cm}$ long. Lower pitchers usually originating laterally from the tendril, to 28 by $4.5 \mathrm{~cm}$, narrowly infundibular in basal half, constricting slightly to a cylindrical upper half, not distinctly hipped, mouth steeply oblique; inner surface glandular in the basal half, waxy portion extending from the constriction at the middle to the top of the pitcher; a pair of wings present on the front of the pitcher, to $2.5 \mathrm{~mm}$ wide, extending from the mouth to $2 / 3$ or the entire length of the pitcher, with fringe elements to $1 \mathrm{~cm}$ long; mouth ovate, peristome flattened, to $3 \mathrm{~cm}$ wide, joined to the pitcher in the inner third; ribs c. $0.5 \mathrm{~mm}$ apart and less than $0.3 \mathrm{~mm}$ tall; inner margin ending in teeth c. $2 \mathrm{~mm}$ long; spur inserted $0.5 \mathrm{~cm}$ from base of lid, to $1.5 \mathrm{~cm}$ long, flattened and branched near the tip into up to 3 distinct points; lid broadly triangular, cordate at base, to 7.5 by $5.5 \mathrm{~cm}$, undersurface completely devoid of nectar glands, with a single filiform appendage originating from the raised midrib c. $1 \mathrm{~cm}$ from the base of the lid, $2.2-4 \mathrm{~cm}$ long, curved about $90^{\circ}$ towards the pitcher mouth, of which the apical $1 \mathrm{~cm}$ is covered with scattered raised nectar glands. Upper pitchers as the lower pitchers but smaller with the tendril originating from the rear of the 


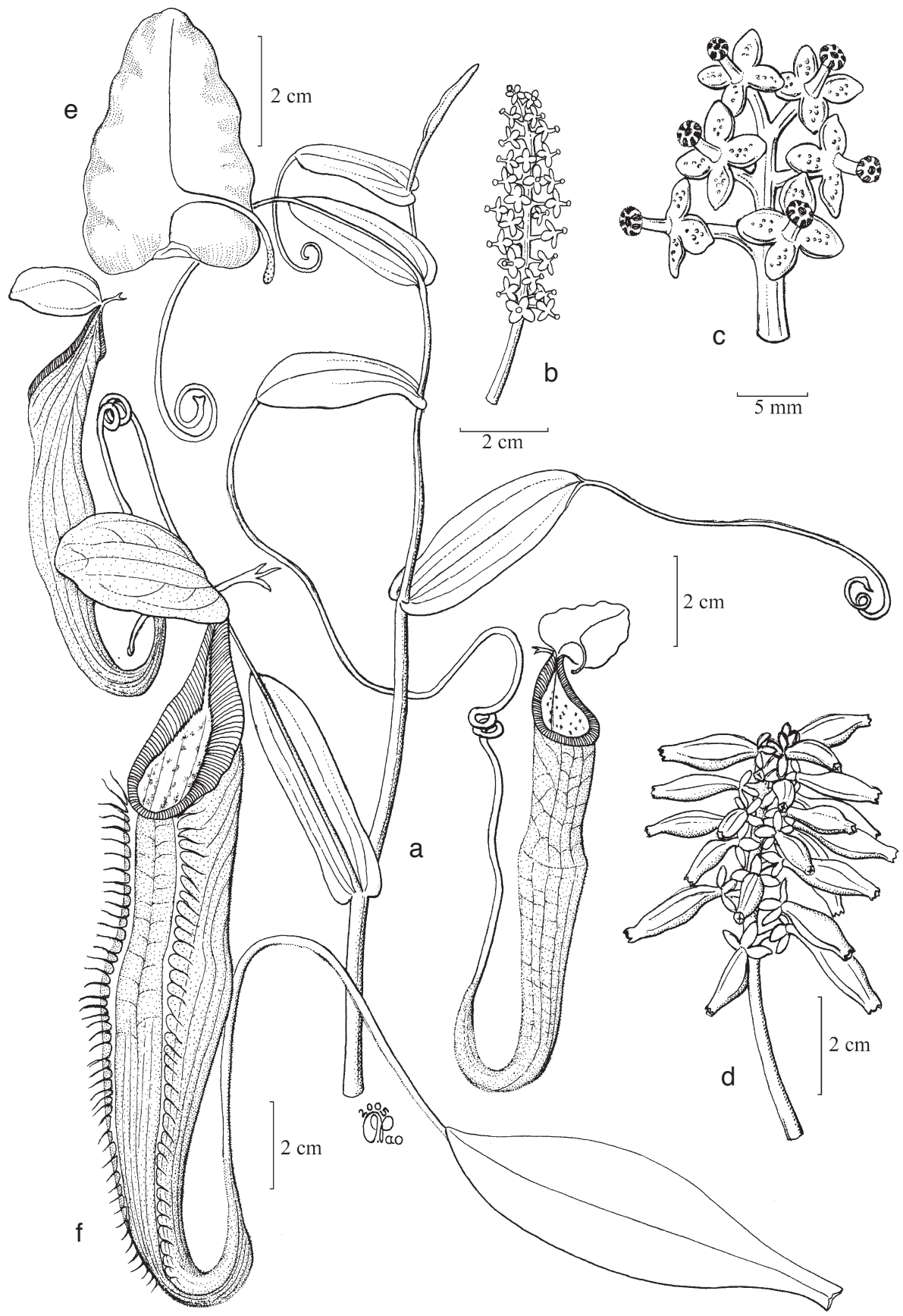

Fig. 2. Nepenthes lingulata Chi.C. Lee, Hernawati \& P. Akhriadi. a. Climbing stem with upper pitchers; b. male inflorescence; c. detail of male inflorescence; d. mature infructescence; e. lower surface of pitcher lid; f. lower pitcher (all from photographs). Drawing by Joseph Pao. 
pitcher, to 12.3 by $2 \mathrm{~cm}$, with a distinct hip at the middle of the pitcher, wings reduced to ribs, fringe elements lacking; mouth ovate to rounded, peristome rounded to slightly flattened, to $0.4 \mathrm{~cm}$ wide, ribs c. $0.3 \mathrm{~mm}$ apart and less than $0.1 \mathrm{~mm}$ tall; lid to 2 by $2 \mathrm{~cm}$. Male inflorescence a raceme, peduncle to $2.3 \mathrm{~cm}$ long, rachis $4-4.5 \mathrm{~cm}$ long, pedicels to $4 \mathrm{~mm}$ long, each bearing a single flower, bracts absent, sepals ovate c. 2 $\mathrm{mm}$ long, staminal column to $2.5 \mathrm{~mm}$ long. Female inflorescence a raceme, peduncle $5.5 \mathrm{~cm}$ long, rachis $3.5 \mathrm{~cm}$ long, pedicels c. $3 \mathrm{~mm}$ long, sepals ovate c. $5 \mathrm{~mm}$ long. Infructescence known from photograph only. Indumentum consisting of very dense long woolly grey-brown depressed hairs on the immature tendrils and outer surface of the pitcher, being caducous on the margins of the leaves; upper surface of lid and margins of lower surface of lid with scattered grey-brown stellate hairs. Colour of living specimens: leaves dark green above sometimes with purple edges and midrib, pale green below, stems of rosettes light green, climbing stems dark purple, inflorescence pale green, sepals light green to reddish purple, tendrils dark purple, outer surface of pitcher dark purplish black, peristome dark purple to black, interior of pitcher pale bluish green with purple spots.

Distribution - Sumatra (Sumatera Utara, Bukit Barisan).

Habitat - Upper montane mossy forest, growing both as an epiphyte and terrestrial.

Etymology - The specific name refers to the tongue-like shape of the lid appendage.

Notes - This species appears most closely related to the recently described N. izumiae, but differs most obviously by the extremely long filiform lid appendage, as well as the triangular lid shape (vs orbicular in N. izumiae), the position of nectar glands, and the very dense long woolly indumentum.

Though numerous species of Nepenthes possess a glandular crest or small projection on the underside of the base of the pitcher lid, an apparently homologous structure throughout the genus, the extreme development of this appendage in $N$. lingulata is unique. In most species the presence of nectar glands on this organ indicates that it is a focal point for the attraction of insect prey, though usually nectar glands are also present elsewhere on the lid. In $N$. lingulata, the underside of the lid is completely devoid of nectar glands, the only such glands being found at the apical end of the appendage. Visiting insects are therefore enticed to the tip of this thin filament where they may find only a tenuous stance and perhaps lose their footing to fall into the pitcher fluid which is positioned directly below. A similar mechanism occurs in the Bornean $N$. bicalcarata which has two thorns that provide a similar function, though these are a structure of the peristome rather than the lid.

Other specimens examined:

Nepenthes izumiae - Clarke, Davis \& Tamin 1309 (holo ANDA), Nepenthes Team NP 60, NP 61 (ANDA).

\section{ACKNOWLEDGEMENTS}

The authors would like to express their gratitude to Dr. Rusjdi Tamin, head of Herbarium Andalas, for his assistance in obtaining access to review specimens and to Dr. Charles Clarke for his comments on the manuscript. Special thanks are also due to Dr. Peter Boyce for preparing the Latin diagnoses and to Mr. Joseph Pao for the excellent line drawings. 


\section{REFERENCES}

Akhriadi, P., Hernawati \& R. Tamin. 2004. A new species of Nepenthes (Nepenthaceae) from Sumatra. Reinwardtia 12: 141-144.

Cheek, M. \& M. Jebb. 2001. Nepenthaceae. Flora Malesiana, Ser. I, 15: 1-157.

Clarke, C. 2001. Nepenthes of Sumatra \& Peninsular Malaysia. Natural History Publications (Borneo), Kota Kinabalu, Sabah.

Clarke, C., T. Davis \& R. Tamin. 2003. Nepenthes izumiae (Nepenthaceae): A new species from Sumatra. Blumea 48: 179-182. 